International Journal of Economics, Business and Accounting Research (IJEBAR)

Peer Reviewed - International Journal

Vol-4, Issue-2, 2020 (IJEBAR)

E-ISSN: 2614-1280 P-ISSN 2622-4771

https://jurnal.stie-aas.ac.id/index.php/IJEBAR

\title{
MODERATION OF NON-PERFORMING FINANCING ON NATURAL UNCERTAINTY CONTRACTS TO THE PROFITABILITY OF ISLAMIC COMMERCIAL BANK IN INDONESIA
}

\author{
Taudlikhul Afkar1, Grahita Chandrarin2, Lilik Pirmaningsih3 \\ 1Department of Accounting, Faculty of Economics, Universitas PGRI Adi Buana \\ 2 Department of Postgraduate, Universitas Merdeka Malang \\ 3Department of Accounting, Faculty of Economics and Business, Universitas Wijaya Kusuma Surabaya \\ Email:afkar@unipasby.ac.id
}

\begin{abstract}
This study intends to provide an overview of the consistency of research results with theoretical and empirical points of view, it is done because many research results are inconsistent with the theory. Quantitative research methods are used to make generalizations using a sample of 14 Islamic Commercial Banks in Indonesia with time series data collection techniques for 5 years. The data analysis technique used is multivariate analysis using the Warp PLS structural equation model. The results showed that the level of profitability of Islamic banks is always overshadowed by the occurrence of credit risk that causes nonperforming financing from financing of the type of natural uncertainty contracts because it is type of financing is a financing that does not provide certainty of results. The results of this study are consistent with agency theory that explains the existence of information asymmetry, and consistent with the theory of mixing that by providing opportunities to manage business to business managers (mudharib/mustyarik) without interference from the owner of the fund (shaibul maal) can lead to the risk of default and thus affect the ability of Islamic banks to obtain profitability.

Keywords: Natural uncertainty contracts, non performing financing, mudharabah, musyarakah, profitability
\end{abstract}

\section{Introduction}

Much research has been done on mudharabah financing and musyarakah financing related to the profitability level of Islamic banks, but it has not provided certainty as a guideline that the results of the research can be used as a consistent reference considering the results of the research are limited to giving an explanation of influence or not, so as not to give an overview of suitability point view by theory. Therefore, this study will provide research results that provide an overview from the perspective of the theory used so as to provide empirical and theoretical analysis of the profitability of Islamic banks through non-performing financing with financing types of natural uncertainty contracts.

The ability to get profit from Islamic banks is certainly inseparable from financing business activities and risk financing problems. Funding provided by Islamic banks based on sharia principles is in accordance with the type of tijarah contracts, which is a contract intended to obtain benefits (Nurhayati \& Wasilah, 2015). It is becomes a business scheme of an Islamic bank in obtaining benefits with natural certainty contracts and natural uncertainty contracts (Karim, 2010). Financing schemes with natural uncertainty contracs can be carried out with mudharabah and musyarakah contracts. But until now the financing that has a dominance in the operations of Islamic banks is murabahah contract, research shows that the largest contribution of financing is from financing of murabahah contract and which does not contribute is the salam contract financing (Iskandar, 2016). 
Financing is one of the biggest forms of business activities of Islamic banks and certainly has a great risk as well (Afkar, 2017a). The risk of loss and the occurrence of fraud will also result in a level of profit even though it may not necessarily result in decreased liquidity (Afkar, 2016). Big risks in financing are certainly in line with the expected benefits are also large, this risk is referred to as financing problems with the category of loss. Therefore there is a need for good risk management from profit loss sharing schemes and other schemes(Rahman et al., 2010).

Along with the increase in assets and financing also followed by problematic financing that can be seen in non-performing financing (NPF). Increased financing should be able to increase profits such as (Haq, 2015) but financing is not necessarily a positive effect on profitability such as mudharabah financing (Afkar, 2017b). It is shows the existence of natural uncertainty contracts such as mudharabah research results are inconsistent there are influential and some are not, including musyarakah financing although it has an influence but is negative. When related to agency theory, it seems irrelevant the results of research that states that financing does not affect profitability because in agency theory explains the existence of information asymmetry that can cause risk so as to enable the influence of profitability that is negative or positive. Profitability is one of the financial performance seen by investors (Tristiningtyas \& Mutaher, 2013). Although profitability is a measure of financial performance in Islamic banks, profitability is not affected by mudharabah financing, musyarakah financing and murabahah financing (Satriawan \& Arifin, 2016), it is contrast to (Permata et al., 2014) which explains that mudharabah financing has a significant negative effect, while musyarakah financing has a positive effect on profitability as measured by return on equity (ROE). Meanwhile, mudharabah financing has a positive effect while musyarakah financing has a negative effect on profitability as measured by return on assets (ROA) (Sodiq \& Chalifah, 2015). That is, profitability is one measure of Islamic bank financial performance because its operations tend to be more than the distribution of financing, besides that ROE and ROA also used as a measure of profitability is Net Operating Margin (NOM) (Tristiningtyas \& Mutaher, 2013).

Distribution of financing also has a risk due to problematic financing that occurs when the receipt of financing is not fully received, in other words there is bad financing so that financing that should have a positive influence on profitability is the other way around, which has a negative effect. There is a need for credit risk management as an instrument in profit-loss sharing (Orhan, 2013). Non-performing financing is a problematic financing that occurs due to the failure of customers to pay their debts so that it affects the ability of Islamic banks to make a profit, on the other side there will not be non-performing financing if they do not conduct financing business activities, meaning that the ability of Islamic banks to earn profits can be weakened when it occurs financing problems.

Mixed theory (Karim, 2010) explains the technical implementation in financing natural uncertainty contracts through mudharabah and musyarakah contracts. It is explains the mix of funds by the owner of the fund (shahibul maal) and the manager of the fund (mudharib) both in full $(100 \%)$ and mutual contribution of funds to venture capital. The fund manager (mudharib) is responsible for managing the business to provide a report for the profit sharing that has been mutually agreed upon, but its relevance to this mixing theory is that when the business is run not yet providing certainty of the results there will be a risk of loss such as defaults by the fund manager (mudharib) caused by business failure so that in this illustration will cause problematic financing called non-performing financing which will ultimately weaken the level of profitability of Islamic banks as the owner of funds (shahibul maal).

Non-performing financing from mudharabah and musyarakah financing has a significant effect on the profitability of Islamic commercial banks which results in a decrease (Mulyaningsih $\&$ Fakhruddin, 2016). The risk of financing with a musyarakah, mudharabah, murabahah, salam, istishna, and ijarah contracts, one of which is the accumulation of late payments, but as long as it is still able to manage these risks, Islamic banks will be better (Rahman et al., 2010). Furthermore (Diallo et al., 2015) also explained that non-performing financing influences mudharabah, musyarakah, murabahah, istishna, ijarah, and qardh financing. However, nonperforming financing (NPF) that occurs in mudharabah financing has a positive effect on 
profitability, but non-performing financing (NPF) that occurs in musyarakah financing has a negative effect (Afkar, 2018).

Inconsistency in the results of previous studies with the theory becomes interesting to do research that sees from an empirical and theoretical point of view. The purpose of this study is to provide a picture of the consistency of research results from a theoretical and empirical point of view regarding moderation of non-performing financing. Based on the literature review problem, a hypothesis can be formulated that the financing of natural uncertainty contracts affects profitability, and non-performing financing becomes a moderating between naural uncertainty contracts and profitability.

\section{Literature Review Profitability}

Profitability is the ability of a business to get profits related to total assets, own equity, and sales, in this case can be used by long-term investors for profitability analysis (Saputra, 2013). Profitability ratios are the result of the ability of company management to measure the size of the profits obtained by a company (Satriawan \& Arifin, 2016).

Return on Assets is one tool to measure the level of profitability as seen from its ability to manage its assets (Umam, 2013). Bank profitability is the ability of banks to generate profits by using the assets they have. Profitability in the banking business reflects the level of business efficiency

This return on equity ratio can be used as an illustration of the rate of return on invested capital or it can be said as the ability to generate profits from the equity owned. This ratio can also be used as a basis for fund owners in providing loans or financing to companies or individuals as well as investor considerations in investment plans. The higher return on equity shows that the company is getting better because in carrying out operations the company has enough capital (Satriawan \& Arifin, 2016).

Islamic banks in their operations do not use the term interest but are better known as profit sharing. Therefore, business activities in channeling funds are carried out with financing, the calculation of which uses the profit margin or agreement. Conventional banks use the term net interest margin (NIM) while Islamic banks use net operating margin (NOM).

Net operating margin is a measurement of the profitability ratio of Islamic banks which is used to determine the ability to manage their productive assets in order to gain profit (Bank Indonesia, 2012). The ability to generate profits by comparing productive assets with operating income and operating costs is referred to as net operating margin (Ihsan, 2013)

\section{Non-Performing Financing}

The collectability of non-performing loans or financing used as a measure by banks in approving or rejecting proposed financing (Bank-Indonesia, 2005): 1) Current, showing that debtors always pay debts on time or current financing, 2) Special Mention, shows that debtor shows the arrears in installment payments between 1-90 days, 3) Substandard, shows that there are arrears in installment payments from debtors between 91-120 days, 4) Doubtful, shows the debtor arrears in installment payments between 121-180 days, 5) Loss, showing the debtor is over 180 days in arrears.

Criteria in the calculation of non-performing financing are included in the quality of substandard, doubtful, and loss with a level of 5\% where more than that percentage can be said to be in an unhealthy or unhealthy financial position. Nevertheless research (Nuha \& Mulazid, 2018) shows that non-performing financing does not affect profitability, whereas (Almunawwaroh \& Marliana, 2018) explains that in his research it is mentioned that non-performing financing has a significant negative effect on profitability as measured by return on assets. This shows the inconsistency of the results of research so it needs to be a concern in developing theory.

Problems in financing are a concern for financial institutions in channeling funds to customers because problematic financing to a standstill is still unable to be overcome at the lowest or zero point even though there are financially reserves for the loss of this transaction. Problematic financing is one component of the bank's health assessment where this condition is caused by the 
customer not paying his obligations. Actually, both Islamic and conventional financial institutions have paid attention to the criteria in the distribution of funding, but it did not rule out the possibility of customers themselves who default in the financing contract. The condition of default from customers can be a failure of business so they are unable to pay installments or because they are actually able to pay debt installments but deliberately delaying payment of debt

\section{Natural Uncertainty Contracts}

Natural uncertainty contracts are contracts or contracts in sharia business that do not provide certainty of income in terms of both quantity and time. The lack of certainty in this income can be seen from the level of income at a positive, negative, or zero level. In sharia business for contracts or contracts of this type, the type of investment contract is usually in the form of a business. Therefore this type of investment contract or contract naturally does not offer fixed and certain income because it sees the results of the business being run (Karim, 2010). This type can be done with mudharabah and musyarakah contracts.

Mudharabah is one of the muamalah activities carried out in collaboration with Shahibul Maal (owner of funds) who provides all funds with Mudharib (fund manager) who acts to manage funds for businesses where profits are shared according to the agreement while financial losses are the responsibility of the owner of the funds (Nurhayati \& Wasilah, 2015).

Musyarakah is an investment cooperation contract for a business in which the parties involved in this contract deposit their mutual capital. It can be said as al-ikhtilath (mixing) two or more people to conduct business activities in sharia. Musyarakah can also be said as a contract of cooperation between two or more parties to manage a business in which each party involved must contribute capital and work with the aim of making a profit (Nurhayati \& Wasilah, 2015).

The nature of capital that is mixed or invested together must be used to finance the business that is run for profit, is not allowed for personal interests or is lent to other parties without the permission of the parties involved. The profits from this business will be divided according to the agreed ratio from the start, but if there is a loss, the risk will be borne by the amount of capital paid by each party in this case is a partner.

\section{Research Methods \\ Research design}

The study design uses a quantitative approach with the aim of generalizing research results related to the research variables used. The population in this study is 14 Islamic Commercial Banks in Indonesia. The sample used is all Islamic commercial banks in Indonesia using convenience sampling techniques or using all Islamic commercial banks in Indonesia with time series data for 5 (five) years, namely 2014 - 2018 through monthly observations issued by the Financial Services Authority (OJK) from joint report of Islamic commercial banks in Indonesia.

\section{Operational Variables}

\section{Exogenous Variables $\left(\mathbf{X}_{1}\right)$}

Exogenous variables in this study are Natural Uncertainty Contracts (NUC) which is a type of financing that does not yet have a certainty of the results made with mudharabah financing $\left(\mathrm{X}_{1.1}\right)$ and musyarakah financing $\left(\mathrm{X}_{1.2}\right)$.

\section{Moderating Variable $\left(\mathbf{X}_{2}\right)$}

Moderating variable in this study is Non-Performing Financing (NPF), which is a problem financing that occurs due to disbursement of funds through Islamic financing as measured by the criteria of Substandard ( $\left.\mathrm{X}_{2.1}\right)$, Doubtful $\left(\mathrm{X}_{2.2}\right)$, and Loss $\left(\mathrm{X}_{2.2}\right)$.

\section{Endogenous Variable (Y)}

Endogenous variable in this study are profitability, which is the company's ability to get measured profits with Return on Assets (ROA) ( $\left.\mathrm{Y}_{1}\right)$, Return On Equity (ROE) ( $\mathrm{Y}_{2}$ ), and Net Operating Margin (NOM) ( $\left.\mathrm{Y}_{3}\right)$. 
Table 1. Outer Model

\begin{tabular}{llll}
\hline Convergent Validity & Discriminant Validity & Reliability & \\
\hline Convergent validity is & Discriminant validity is & Reliability testing uses composite \\
used to test the validity & used to test the validity & reliability (combined) with the condition \\
of indicators with a & of the loading factor $>$ & that the reliability value $>0.70$, and using \\
factor load value $>0.30$ & cross loading factor. & $\begin{array}{l}\text { the internal consistency reliability test with } \\
\text { and a p value }<0.001 .\end{array}$ & $\begin{array}{l}\text { the condition that the reliability value }> \\
\end{array}$ \\
\hline
\end{tabular}

Table 2. Inner Model

t - test

Hypothesis testing is done to test the Average Path Coefficient with fit criteria $p<$ exogenous variables against endogenous with 5

one intervening variable. Testing is done by path analysis so that the t-test is used with criteria:

p-value $<0.10$ weakly significant

p-value $<0.05$ significant

p-value $<0.01$ highly significant

\section{5}

Average R-Squared with fit criteria $\mathrm{p}<5$

Average adjusted R-squared with fit criteria $p$ $<5$

Structural Equation Model is:

$\mathrm{Y}_{1}=\mathrm{b}_{1} \mathrm{X}_{1}+\mathrm{b}_{2} \mathrm{X}_{2}+\mathrm{bX}_{1} * \mathrm{X}_{2}$

\section{Results and Discussions \\ Result \\ Validity Test}

Table 3. Convergent and Discriminant Validity

\begin{tabular}{ccccccc}
\hline $\begin{array}{l}\text { Combined loadings } \\
\text { and cross-loadings } \\
*\end{array}$ & $\mathrm{Y}$ & \multicolumn{1}{c}{$\mathrm{X}_{2}$} & $\mathrm{X}_{1}$ & $\mathrm{X}_{2} * \mathrm{X}_{1}$ & $\mathrm{SE}$ & $\mathrm{p}$-value \\
\hline $\mathrm{Y}_{1}$ & $(0.972)$ & -0.024 & -0.180 & 0.064 & 0.092 & $<0.001$ \\
\hline $\mathrm{Y}_{2}$ & $(0.929)$ & 0.079 & 0.313 & 0.004 & 0.093 & $<0.001$ \\
\hline $\mathrm{Y}_{3}$ & $(0.980)$ & -0.051 & -0.119 & -0.067 & 0.092 & $<0.001$ \\
\hline $\mathrm{X}_{2.1}$ & 0.495 & $(0.701)$ & -0.596 & -0.391 & 0.101 & $<0.001$ \\
\hline $\mathrm{X}_{2.2}$ & -0.377 & $(0.814)$ & 0.149 & 0.433 & 0.097 & $<0.001$ \\
\hline $\mathrm{X}_{2.3}$ & 0.077 & $(0.526)$ & -0.566 & 0.150 & 0.107 & $<0.001$ \\
\hline $\mathrm{X}_{1.1}$ & -0.794 & 0.047 & $(0.384)$ & -0.138 & 0.113 & $<0.001$ \\
\hline $\mathrm{X}_{1.2}$ & 0.794 & -0.047 & $(0.385)$ & 0.138 & 0.113 & $<0.001$ \\
\hline
\end{tabular}

Souces: processed by Warp PLS

Table 3 shows the results of the convergent and discriminant validity tests that all indicators used in this study meet the convergent validity and discriminant validity with loadings $>$ cross loadings. This means that each indicator variable used in this study is valid, other than that the value of each indicator shows a p-value $<0.001$ so that it can be said to be a highly significant level. 
Table 4. Reliability

\begin{tabular}{llll}
\hline & $\begin{array}{l}\text { composite } \\
\text { reliability }\end{array}$ & $\begin{array}{l}\text { Cronbach's } \\
\text { alpha }\end{array}$ & result \\
\hline $\mathrm{Y}$ & 0.973 & 0.958 & Reliable \\
\hline $\mathrm{X}_{2}$ & 0.685 & 0.643 & Reliable \\
\hline $\mathrm{X}_{1}$ & 0.757 & 0.771 & Reliable \\
\hline $\mathrm{X}_{1} * \mathrm{X}_{2}$ & 0.759 & 0.621 & Reliable \\
\hline Sources: Processed by Warp PLS & &
\end{tabular}

Table 4 shows the level of reliability using the 2 (two) measurement method, namely composite reliability and Cronbach's alpha. All variables used in this study indicate the value of reliability> 0.600 so that it can be said that all the research instruments used are reliable.

\section{Hypothesis Test}

Table 5. Hypothesis Test Result

\begin{tabular}{lllllllll}
\hline \multicolumn{3}{c}{ coefficients } & \multicolumn{7}{c}{ p-value } \\
\hline & $\mathrm{Y}$ & $\mathrm{X}_{2}$ & $\mathrm{X}_{1}$ & $\mathrm{X}_{1} * \mathrm{X}_{2}$ & $\mathrm{Y}$ & $\mathrm{X}_{2}$ & $\mathrm{X}_{1}$ & $\mathrm{X}_{1} * \mathrm{X}_{2}$ \\
\hline $\mathrm{Y}$ & 0.363 & 0.412 & 0.383 & $\mathrm{Y}$ & & 0.001 & $<0.001$ & $<0.001$ \\
\hline $\mathrm{X}_{2}$ & \multicolumn{9}{c}{$\mathrm{X} 2$} \\
$\mathrm{X}_{1}$ & \multicolumn{9}{c}{$\mathrm{X} 1$} \\
$\mathrm{X}_{1} * \mathrm{X}_{2}$ & \multicolumn{7}{c}{$\mathrm{X} 1 * \mathrm{X} 2$} \\
\hline
\end{tabular}

Sources: Processed by Warp PLS

Table 5 explains the direct effects and indirect effects between variables in this study. First, Natural Uncertainty Contracts $\left(\mathrm{X}_{1}\right)$ show coefficients of 0.412 with $\mathrm{p}$-value $<0.001$, it is means that Natural Uncertainty Contracts $\left(\mathrm{X}_{1}\right)$ as measured by mudharabah financing and musyarakah financing have a direct effect on profitability (Y) as measured by ROA, ROE and NOM. Second, Non Performing Financing $\left(\mathrm{X}_{2}\right)$ shows coefficients of 0.363 with p-value $<0.001$, it is means that Non Performing Financing $\left(\mathrm{X}_{2}\right)$ as measured by the indicator Substandard, Doubtful, and Loss has a direct effect on Profitability (Y) which measured by ROA, ROE, and NOM. Third, it shows the indirect effect of Natural Uncertainty Contracts $\left(\mathrm{X}_{1}\right)$ and Non Performing Financing $\left(\mathrm{X}_{2}\right)$ on Profitability (Y) with path coefficients of 0.383 with p-value $<0.001$, it means that Non Performing Financing $\left(\mathrm{X}_{2}\right)$ can be a moderating variable between Natural Uncertainty Contracts $\left(\mathrm{X}_{1}\right)$ and Profitability $(\mathrm{Y})$.

Table 6. Absolute Contributions

\begin{tabular}{lcccc}
\hline $\begin{array}{l}\text { Absolute } \\
\text { Contribution }\end{array}$ & $\begin{array}{l}\text { Total } \\
\text { effects }\end{array}$ & Squared & $\%$ & Contribution $\%$ \\
\hline X2 to Y & 0,363 & 0,132 & 100 & 1,32 \\
\hline X1 to Y & 0,412 & 0,170 & 100 & 1,70 \\
\hline X1*X2 to Y & 0,383 & 0,147 & 100 & 1,47 \\
\hline \multicolumn{2}{r}{ Sources: Processed by Warp PLS } & & &
\end{tabular}

Absolute Contribution is the distribution of each exogenous variable and moderation variable in the research results that leads to endogenous variables which ultimately provide the contribution value of the role of each variable. Table 6 shows the absolute contribution of Natural Uncertainty Contracts $\left(\mathrm{X}_{1}\right)$ to Profitability $(\mathrm{Y})$ of $1.70 \%$. Non-Performing Financing $\left(\mathrm{X}_{2}\right)$ to Profitability $(\mathrm{Y})$ of $1.32 \%$. While through moderation Natural Uncertainty Contracts $\left(\mathrm{X}_{1}\right)$ and Non-Performing Financing $\left(\mathrm{X}_{2}\right)$ to Profitability $(\mathrm{Y})$ gave an absolute contribution of $1.47 \%$. This 
shows that each variable has a contribution to the amount of each, but which shows a greater contribution is Natural Uncertainty Contracts $\left(\mathrm{X}_{1}\right)$ directly, then reinforced by the moderation of Non-Performing Financing $\left(\mathrm{X}_{2}\right)$.

Table 7. Goodness of Fit

\begin{tabular}{lllll}
\hline No & Model and Quality Indices & Fit Criteria & Result & $\begin{array}{l}\text { Model } \\
\text { Fit }\end{array}$ \\
\hline 1 & $\begin{array}{l}\text { Average Path Coefficient } \\
\text { (APC) }\end{array}$ & $\mathrm{p}<0.05$ & $0.386, \mathrm{p}<0.001$ & Good \\
\hline 2 & Average R-squared (ARS) & $\mathrm{p}<0.05$ & $0.434, \mathrm{p}<0.001$ & Good \\
\hline 3 & Average Adjusted R-squared & $\mathrm{p}<0.05$ & $0.404, \mathrm{p}<0.001$ & Good \\
\hline 4 & Average block VIF (AVIF) & $\begin{array}{l}\text { Acceptable if } \leq 5, \text { ideally } \\
3.30\end{array}$ & 1.031 & Ideal \\
\hline 5 & $\begin{array}{l}\text { Average full colliniearity VIF } \\
\text { (AFVIF) }\end{array}$ & $\begin{array}{l}\text { Acceptable if } \leq 5, \text { ideally } \leq \\
3.30\end{array}$ & 1.461 & Ideal \\
\hline
\end{tabular}

Sources: Processed by Warp PLS

Table 7 shows the models of fit quality indices used as indicators of the worthiness of the inner model. Average Path Coefficient (APC) or the average path coefficient of 0.386 with a significance level of p-value $<0.001$, meaning that the coefficient on each path has a significant influence of exogenous variables on endogenous variables and also moderation models on endogenous variables supported by the fit model in good condition.

Average R-squared (ARS) shows 0.434 with $\mathrm{p}$-value $\mathrm{p}<0.001$ and Average Adjusted Rsquared of 0.404 with $p$-value $p<0.001$, meaning that it shows a significant influence of $43.40 \%$ from exogenous variables to endogenous variables and also moderation models for endogenous variables which are supported by fit models in good conditions. While the remaining $56.70 \%$ is influenced by other variables not used in this study.

Average block VIF (AVIF) value of $1,031<3,300<5,000$ including the ideal category and the Average Full Colliniearity VIF (AFVIF) value of 1,461<3,869<5,000 are included in ideal conditions. It is means that the results of this analysis indicate that each variable in this study is free from multicollinearity. Free from multicollinearity shows that each variable is not interconnected or does not have a significant correlation so that each variable used in this study is independent or mutually independent.

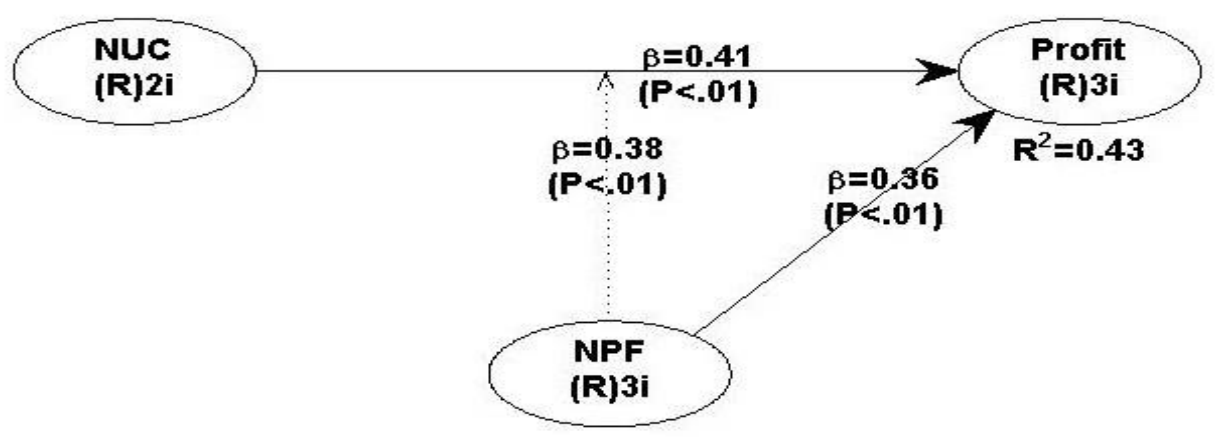

Figure 1. Structural Equation Model

Figure 1 shows the results of calculating coefficient of each variable as a result of the structural equation model using the PLS Warp. There are two structural equation models formed namely direct correlation and correlation through moderation. Correlation of exogenous and endogenous variables can be shown through the path coefficient and the significance level of pvalue. Relevance of Agency theory in this structural model can be demonstrated in the financing mechanism carried out with natural certainty contracts and natural uncertainty contracts. The 
results of data analysis show that natural uncertainty contracts $\left(\mathrm{X}_{1}\right)$ have a significant correlation to profitability with a path coefficient value of 0.41 and $\mathrm{p}$-value $<0.01$. It is means that the financing mechanism carried out by Islamic banks with income uncertainty schemes also affects profitability. The impact of channeling funds through financing results in non performing financing $\left(\mathrm{X}_{2}\right)$ which also affects profitability as shown in Figure 1 showing the path coefficient value of 0.36 and $\mathrm{p}$-value $<0.01$. other than that observations on non performing financing $\left(\mathrm{X}_{2}\right)$ show that moderating between natural uncertainty contracts and profitability $(\mathrm{Y})$ is acceptable because the calculation results show a path coefficient of 0.38 and p-value $<0.01$, meaning that the result of channeling funds through financing raises non-performing financing which ultimately led to a decline in the ability of Islamic banks to earn profits. The structural equations obtained in this study are as follows:

$\mathrm{Y}=0.41 \mathrm{X}_{1}+0.36 \mathrm{X}_{2}+0.38 \mathrm{X}_{1} * \mathrm{X}_{2}$

\section{Discussions}

Natural uncertainty contracts are actually an illustration of financing used by Islamic banks in order to get profit with uncertainty schemes in revenue because in this type of transaction will use mudharabah and musyarakah (Karim, 2010). Mudharabah is simply a financing that is carried out by providing opportunities in business management to manage financing funds with the distribution of results according to the agreed ratio, but the loss is borne by the owner of the fund. Likewise, musyarakah, is simply a business cooperation agreement in which each acts as a partner with profit sharing according to the agreed ratio while losses are borne by both parties according to the contribution of paid capital (Nurhayati \& Wasilah, 2015).

Financing provided by Islamic banks cannot be separated from credit risk, especially in financing schemes that use uncertainties such as mudharabah (Diallo et al., 2015) but in their research explain that musyarakah financing does not have credit risk. This is different from research (Afkar, 2017b) which explains that mudharabah financing has no influence on profitability. While in this study it was found that credit risk calculated by non-performing financing became a variable that moderated the acquisition of profitability levels of Islamic banks in Indonesia, meaning that the greater the financing provided by Islamic banks through mudharabah and musyarakah financing because this type of financing is financing for businesses that have not provided the certainty of the results so that there is a high risk. That is, in an effort to obtain profits through Islamic financing there are still risks that will occur in Islamic banking (Abedifar et al., 2013).

The risk arising from financing this type of mudharabah and musyarakah does require special attention because by providing opportunities for business managers to manage their business without the intervention of the fund owner can cause information asymmetry that can lead to accounting fraud (Afkar, 2016). Agency theory explains that it allows the assimilation of information between the business manager and the owner of the fund, which sometimes causes misperceptions in translating the wishes of the business owner so that the manager (in this case is agent) will try his best to manage the business but in financial reporting can be done by manipulation or as if financial condition is not good. This is what might be applied through the Fatwa of the Indonesian Ulema Council (Dewan Syariah Nasional Majelis Ulama Indonesia (DSN-MUI), 2000) to avoid cheating.

Islamic banks as intermediary institutions with their role as social institutions and financial institutions cannot be separated from the interests of maintaining the continuity of their business entities through profitability. While this is more often used by many studies assessing through ROA and ROE as a measure of a company's ability to make a profit, it does not provide a certainty of research results that have consistency of results so that it can be a guideline for researchers that ROA and ROE become a definite measure to measure profitability. This study adds an indicator of Net Operating Margin (NOM) as one measure of profitability of Islamic banks presented in the financial statements, the aim is to see the operational level of Islamic banks in real terms. This is as done by (Ascarya \& Yumanita, 2010) who use the term Net Interest Margin (NIM) because it compares conventional banks with Islamic banks. 
Overall this study found that the risk of non-performing loans as indicated by the occurrence of non-performing financing had an influence on the ability of Islamic banks to obtain the level of business profitability from financing the type of natural uncertainty contracts. Although the results of this study differ from some previous research results, but when viewed from the agency theory, it is very possible to cause problems with financing, namely bad credit due to various backgrounds such as defaults on customers due to bankruptcy, delaying payments, and the existence of information asymmetry (Rodoni \& Yaman, 2018) about its business reports, or other matters that cause uncertainty of results.

Furthermore, when viewed from the theory of mixing, it is very possible that financial risks occur in sharia financing because through financing provided by sharia banks (shaibul maal) mixed in one form of business activities managed by fund managers (Mudharib) without any intervention in business activities, the risks finance will always overshadow (Rodoni \& Yemen, 2018) even though the distribution of funding is still carried out with the principle of prudence. Maybe this is a weakness in financing the type of natural uncertainty contracts, but when viewed from the side of the actual benefit the goal is to provide convenience in improving the economy through the real sector, namely productive business activities, apart from that it still implements sharia compliance (Susilo \& Anam, 2018).

\section{Conclusions}

The level of profitability of Islamic banks in Indonesia is directly affected by the level of financing provided through natural uncertainty contracts, meaning that the greater the financing provided, the level of profitability will also increase but still overshadowed by the risk of non-performing loans that lead to non-performing financing, which in turn will weaken the ability of Islamic banks earns profit. The findings in this study are that non-performing financing will always overshadow the profitability of Islamic banks when providing disbursement and through financing with a type of natural uncertainty contracts so that it needs to be considered at the time of the contract by strengthening wa'ad which may not have been assisted in the contract so that it can become a guideline if it occurs neglect of business management and the risk of unexpected losses due to economic conditions or disasters.

\section{References:}

Abedifar, P., Molyneux, P., \& Tarazi, A. (2013). Risk in islamic banking. Review of Finance, 17(6), 2035-2096. https://doi.org/10.1093/rof/rfs041

Afkar, T. (2016). Efektivitas Pengendalian Preventif, Pengendalian Detektif, dan Pengendalian Represif Terhadap Pencegahan Kecurangan Akuntansi. Majalah Ekonomi, 21(2), 211-225.

Afkar, T. (2017a). Analisis Pengaruh Kredit Macet Dan Kecukupan Likuiditas Terhadap Efisiensi Biaya Operasional Bank Umum Syariah Di Indonesia. AJIE, 2(2), 177-192. https://doi.org/10.20885/ajie.vol2.iss2.art8

Afkar, T. (2017b). Influence Analysis Of Mudharabah Financing And Qardh Financing To The Profitability Of Islamic Banking In Indonesia. AJIE - Asian Journal of Innovation and Entrepreneurship, 02(03), 340-351.

Afkar, T. (2018). Influence Analysis Of Non Performing Financing By Profit-Loss Sharing Financing Contract To The Profitability Of Islamic Commercial Bank In Indonesia. AKRUAL: Jurnal Akuntansi, 10(1), 1-14. https://doi.org/10.26740/jaj.v10n1.p1-14

Almunawwaroh, M., \& Marliana, R. (2018). Pengaruh Car,Npf Dan Fdr Terhadap Profitabilitas Bank Syariah Di Indonesia. Amwaluna: Jurnal Ekonomi Dan Keuangan Syariah, 2(1), 117. https://doi.org/10.29313/amwaluna.v2i1.3156

Ascarya, A., \& Yumanita, D. (2010). The Determinants of Net Interest Margin in Conventional and Islamic Banks in Indonesia. International Conference on Eurasian Economies 2010, 252-257. https://doi.org/10.36880/c01.00171

Bank-Indonesia. (2005). Peraturan Bank Indonesia Nomor:7/2/PBI/2005 Tentang Kualitas Aktiva Bank Umum. 52(1), 1-5. 
Dewan Syariah Nasional Majelis Ulama Indonesia (DSN-MUI). (2000). Fatwa Dewan Syariah Nasional No. 17/DSN-MUI/IX/2000 tentang Sanksi Atas Nasabah Mampu yang MenundaNunda Pembayaran.

Diallo, O., Fitrijanti, T., \& Tanzil, N. D. (2015). Analysis of the influence of liquidity, credit and operational risk, in Indonesian islamic bank's financing for the period 2007-2013. Gadjah Mada International Journal of Business, 17(3), 279-294.

Haq, R. N. A. (2015). Pengaruh Pembiayaan dan Efisiensi Terhadap Profitabilitas Bank Umum Syariah. Perbanas Review, 1(1), 107-124.

Iskandar, R. (2016). Di Indonesia Berdasarkan Jenis Akad Periode Tahun 2008-2013. Maqdis : Jurnal Kajian Ekonomi Islam, I(2), 237-248. http://journal.febi.uinib.ac.id/index.php/maqdis/article/view/48

Karim, A. A. (2010). Perbankan Islam Analisis Fiqih dan Keuangan. Jakarta : PT. Raja Grafindo Persada.

Mulyaningsih, S., \& Fakhruddin, I. (2016). Pengaruh Non Performing Financing Pembiayaan Mudharabah Dan Non Performing Financing Pembiayaan Musyarakah Terhadap Profitabilitas Pada Bank Umum Syariah Di Indonesia. Jurnal Manajemen Dan Bisnis MEDIA EKONOMI, XVI(1), 196-206.

Nuha, V. Q. Q., \& Mulazid, A. S. (2018). Pengaruh Npf, Bopo Dan Pembiayaan Bagi Hasil Terhadap Profitabilitas Bank Umum Syariah Di Indonesia. Al-Uqud: Journal of Islamic Economics, 2(2), 168. https://doi.org/10.26740/al-uqud.v2n2.p168-182

Nurhayati, S., \& Wasilah. (2015). Akuntansi Syariah Di Indonesia. Jakarta : Selemba Empat.

Orhan, Z. H. (2013). Credit risk management pertaining to profit and loss sharing instruments in Islamic banking. Journal of Financial Reporting and Accounting, 11(1), 80-91. https://doi.org/10.1108/jfra-03-2013-0014

Permata, R. I. D., Yaningwati, F., \& A, Z. Z. (2014). Analisis pengaruh pembiayaan mudharabah dan musyarakah terhadap tingkat profitabilitas (Return On Equity) (Studi Pada Bank Umum Syariah yang Terdaftar di Bank Indonesia periode 2009-2012). Jurnal Administrasi Bisnis, 12(1), 1-9.

Rahman, R. A., Tafri, F. H., \& Aljanadi, Y. (2010). Instruments and risks in Islamic financial institutions. Malaysian Accounting Review, 9(2), 11-21.

Rodoni, A., \& Yaman, B. (2018). Asymmetric Information and Non-Performing Financing: Study in The Indonesian Islamic Banking Industry. Al-Iqtishad: Jurnal Ilmu Ekonomi Syariah, 10(2). https://doi.org/10.15408/aiq.v10i2.7392

Saputra, A. W. (2013). Pengaruh Non Performing Finance (NPF) Pembiayaan Mudharabah dan Non Performing Finance (NPF) Pembiayaan Musyarakah Terhadap Profitabilitas Perbankan Syariah (Studi Kasus pada PT. Bank Syariah Mandiri Tahun 1999-2013). Syariah Paper Accounting. FEB UMS, ISSN 2460-0784, 10.

Satriawan, A., \& Arifin, Z. (2016). Analisis Profitabilitas Dari Pembiayaan Mudharabah, Musyarakah, Dan Murabahah Pada Bank Umum Syariah Di Indonesia Periode 2005-2010. Media Riset Akuntansi, Auditing Dan Informasi, 12(1), 1. https://doi.org/10.25105/mraai.v12i1.580

Sodiq, A., \& Chalifah, E. (2015). Pengaruh Pendapatan Mudharabah Dan Musyarakah Terhadap Profitabilitas (Roa) Bank Syariah Mandiri Periode 2006-2014. Jurnal Ekonomi Syariah, $3(1), 27-47$.

Susilo, E., \& Anam, A. K. (2018). Sharia Complience Akad Berbasis Natural Uncertainty Contract (Nuc) Lembaga Keuangan Mikro Syariah Di Kabupaten Jepara. Al-Uqud : Journal of Islamic Economics, 2(1), 20-37. https://doi.org/10.26740/al-uqud.v2n1.p20-37

Tristiningtyas, V., \& Mutaher, O. (2013). Gdp Sebagai Variabel Kontrol Pada Perbankan Syariah Di Indonesia. Jurnal Akuntansi Indonesia, 3(2), 131-145.

Umam, K. (2013). Manajemen Perbankan Syariah. Bandung: Pustaka Setia 